\title{
Evaluation and financial risk management of urban renewal projects in partnership with public and private
}

\author{
Ehsan Hassani $^{\mathrm{a}^{*}}$ and Masoud Babakhani ${ }^{\mathrm{b}}$
}

${ }^{a}$ Department of Industrial Engineering, Iran University of Science \& Technology, Tehran, Iran

${ }^{b}$ Department of Industrial Engineering, Islamic Azad University, Karaj Branch, Karaj, Iran

\begin{tabular}{|c|c|}
\hline ARTICLEINFO & $\overline{A B S T R A C T}$ \\
\hline $\begin{array}{l}\text { Article history: } \\
\text { Received March 15, } 2011 \\
\text { Received in Revised form } \\
\text { June, 20, } 2011 \\
\text { Accepted 22 June } 2011 \\
\text { Available online } \\
\text { 26 June 2011 } \\
\text { Keywords: } \\
\text { Public private financial } \\
\text { Partnership } \\
\text { Risk management } \\
\text { Slum areas } \\
\text { Financial analysis }\end{array}$ & $\begin{array}{l}\text { Financing plays an important role for renewal of old city building is find suitable financing } \\
\text { plan. A proper financial management in one hand has a direct relationship with project main } \\
\text { factors such as: time, cost and quality of the project, and on the other hand, achieving project } \\
\text { goals requires a comprehensive insight of project, stockholders as well as other relative } \\
\text { situation in regard with the project. Considering the complication of execution such projects } \\
\text { and the number of shareholders, one of the best attitudes towards the project management is } \\
\text { risk management. This research is a qualitative and practical, which reviews the effects of } \\
\text { project management factors on financial return of urban renewal sachem. The required } \\
\text { information gained through a survey and via questionnaire and interviews with specialists. This } \\
\text { article first describes the public private financial partnership and then, based on the results } \\
\text { gained from a case study done on one of the renewal schemes in Mashhad metropolitan areas. } \\
\text { Next, it identifies and evaluates of positive and negative risks, which lead to threats and } \\
\text { opportunities will be performed and will attempt to respond the existent risks. Finally, we } \\
\text { provide a framework for the risk assessment of the housing units. }\end{array}$ \\
\hline
\end{tabular}

\section{Introduction}

One of the most important issues for a civil society is live in secure urban areas, which could resists against natural incidents such as earthquake, flood, etc. It is important for the people who live in urban regional areas to make sure that the houses are renovated and they could resist against natural disasters. However, any renovation operations would need significant amount of investment and such investment must be justified in terms of cost/benefit return. There are many cases in the world, where municipalities are in charge of the management of such projects and the financing fulfillment mostly rely on the availability of public or other organizations financial resource. However, when there is a shortage of funding or budgets, there may be some risks associated with accomplishing such tasks. In fact, when the required financial resources exceed municipalities' budget, uncertainties in supplying financial resources and along with the cease of such projects would be inevitable. Therefore, definition, analysis and management of relevant risks play crucial role to reach the project goals.

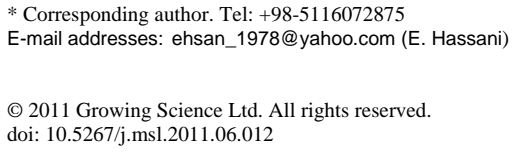


Mashhad, as the religious capital of Islamic Republic of Iran, hosting millions of Razavi Holly Shrine prayers each year and this justification gives a great importance to the development of urban infrastructures and facilities more than other metropolitan areas. Existence slum areas around the holly shrine not only create unpleasant picture of this region but also it presents the city officials on expanding their social services. There are also other social and cultural issues arising as long as the old and unsafe infrastructure exists within the city.

The aim of this research is to identify and evaluate problems, barriers to cooperate public, and private sectors in financing of urban renewal projects. The main goal of this paper is to find out risk management approaches to overcome the threats and take advantage of opportunities and eventually improvement of the project financing in partnership with public and private. The proposed framework of this paper considers important factors influencing on financing such projects and prioritize them through a comprehensive model.

\section{Literature review}

There are different aspects on assessing an urban regeneration project such as risk evaluation, performance evaluation, etc. (Rondinelli, 1990, Colin, 1998). McGreal et al. (2000) provided a framework for assessing private sector finance in urban regeneration in terms of investor and noninvestor perspectives. Yescombe (2007) in his book extensively discussed the principles and policies in participating private and public partnership. Adair et al. (2005a) presented an appraisal practice, in particular the bases of valuation, availability and utilization of data, reporting of the value figure and the management of risk of the land, which is the subject of construction renovation. The valuation of urban regeneration properties is believed to be one of the most important issues in the appraisal of projects due to a lack of data transparency in urban regeneration markets and complexities of public sector grant procedures and their study was a good attempt to address these issues. Adair et al. (2005b) constructed some regeneration property performance indicators consistent with the CBRE rent index and average yield monitor to help investor evaluate construction projects. In fact, this method helps us measure the property investment performance quantitatively from regeneration areas that previously has not been available to investment institutions and decision makers. However, Empirical evidence, however, recommends that there are different factors to be considered other than performance indicators (Guy et al., 2002). In fact, geographic location and in particular distance from important locations appears to have a stronger influence on investment flows than economic performance (Callender \& Key, 1996).

\subsection{Question and hypothesis}

In this paper, we are concerned to look for appropriate answers for the following questions,

- What are the threats and opportunities of public private partnership in financing urban renewal projects?

- What is the role of management of project main factors including: time, cost and income of urban renewal projects on economic returns of the scheme and attraction of investors?

The main hypothesis of this study is that by making use of public private investment strategy in financing urban renewal projects, it would be possible to accelerate the rate of introduction and implementation of such project and increase in the return of the project.

\section{Research methodology}

This study is a qualitative and practical and the methodology is a surveying as a case study and the content of the study deals with the evaluation of financing of urban renewal project by public private partnership. To achieve appropriate results, the study is implemented in one of the large scale regeneration projects around Mashhad holly shrine. The required information are gathered through a survey and interview with specialists working in the project and the data is collected via a 
questionnaire. The risk management is performed based on project management body of knowledge (PMBOK), as the risk management principal reference. The identification and evaluation of relevant risks, including threats and opportunities, implemented by means of documentation reviews, brainstorming, and assumption analysis methods. Regarding the gained information, a long list of probable risks will be acquired as a comprehension reference of risks. In order to evaluate the project risks, a two dimensions matrix, which consists of risk probability and risk influence have been set and each risk is positioned based on its score. Then, the influence of three scale factors including: the influence of time, the ability of risk management and the degree of risk familiarity have been exerted the scores. The priorities of the risks are identified based on the score of each risk and based on all other scores. Next, ten most important risks are identified to form the short list of the most significant risks to be responded. It is necessary to note that the required information for this study gained by making use of library books, interviews and questionnaire. After studying the relevant books and papers and reviewing the project documentations, separate interviews with 24 experts of the project specialists, mentioned in Table 1, are conducted. In order to identify and evaluate the defined risks, the risk information will be gained through the supreme managers of the three main stock holders including: client, bidder companies and Consultant Company.

\section{Table 1}

Information of respondents to questionnaire

\begin{tabular}{lllcc}
\hline Educational level & Position & No. & Work experience & Work experience in urban renewal projects \\
\hline Bachelor degree & Investor, Executers & 10 & $6-15$ & $3-5$ \\
Master degree & Investor, Executers & 13 & $4-10$ & $2-5$ \\
PhD degree & Consultant & 1 & 1 & 1 \\
\hline
\end{tabular}

In this research, the effect of financial risk management in public private partnership financing as an independent variable and on renewal schemes the economic returns as a dependent variable are studied. It should be also considered that the mentioned independent factor also influenced by the project management main factors such as costs, time, and incomes of the project. The other influential factors on the risk management process are risks probability, the magnitude of risk effect, coefficient of time influence, ability of risk management, and the amount risk familiarity. In this research, we have studied one of the main renewal projects around the Razavi Holly Shrine entitled Saheb Al Zaman Boulevard constructed in an area of 17000 square meter and sub structures in 6000 square. The required financial resources have been provided via a public private partnership. In addition to identification and evaluation of the project risks and preparing a list of comprehensive relevant risks, the financial risks will be analyzed and properly responded. It is forecasted that responses would be helpful and could be applicable in similar projects in other metropolitan areas.

\subsection{Conceptions and principals of the research}

One of the necessary steps is have an appropriate definition on urban decayed areas or slum regions. According to Iranian high council of housing and architecture, if at least $50 \%$ of a region has the following criteria, it can be considered as slum regions,

1. Instability, which means the poor and not resentencing structures, especially resistance to earthquake, which is not constructed based on the Iranian national building codes of practices,

2. Inaccessibility and existence of routs with inadequate width for driving vehicles and have less than 6 meter width,

3. Condensed regions, which have small blocks with areas less than 200 meter square.

\subsection{The principals of public private partnership financing}

It seems that the public private partnership firstly introduced in United States of America and refers to public private partnership in investment on educational projects after 1950s. This partnership in 1960s was more widely used in financing of urban renewal projects. In spite of not being a unique 
definition for public private partnership, all the definitions declare the same characteristics. The contracts of financial partnership have five characteristics in common including:

1. All of these partnerships are corporation of two or more sections in which at least one of them is public section and one of them is also private one,

2. Each of these sections is of the main contract parts that have their own negotiation ability,

3. The two parts have a continuous and sustainable relationship,

4. This partnership includes collaborative responsibilities, results and activities.

This issue means that the public and private partnership which is initiated with a relationship between public and private section and the public section only makes use of the private section consultants and the decision and policy making is in the public section hands, is completely different. The advantages of public private financial partnership for the public sections are: increment of the governmental capacities in development of more complicated schemes, acceleration the rate of innovation and creativity attitudes, decrease in cost of projects, decrease in projects implementation time, transferring the whole or parts of the risks of a plane to cooperative private section, achieving the novel skills, experiments and newly developed technologies, reaching a proper and vivid insight into investors. Table 2 introduces different models and their descriptions of public private partnership financing.

\section{Table 2}

Different models of public private partnership financing

\begin{tabular}{|c|c|}
\hline Model & Description \\
\hline ASSET sales & sales of the extra assets by private section \\
\hline Wider markets & Introduction capacities and abilities of the private section for a better use of assets \\
\hline Sales of business & Sale of public business shares by flotation or trade sale \\
\hline Partnership companies & $\begin{array}{l}\text { Using private possessions beside public assets and preserve the profits, policies and goals of } \\
\text { the public section by partnership contracts }\end{array}$ \\
\hline $\begin{array}{l}\text { Private finance } \\
\text { Initiative }\end{array}$ & $\begin{array}{l}\text { The public section contract to purchase pre- defined services or outcomes including } \\
\text { construction buildings, preserving necessary facilities and buildings }\end{array}$ \\
\hline Joint ventures & $\begin{array}{l}\text { A partnership in which public and private section gathering their experiences } \\
\text { and assets in on one place to enrich the future value of the scheme }\end{array}$ \\
\hline Partnership investments & $\begin{array}{l}\text { A partnership in which public section helps a private section in financing a } \\
\text { project invested by private section in order to get scheme profit shares. }\end{array}$ \\
\hline Policy partnership & $\begin{array}{l}\text { A contract in which individuals or groups are employed for development or implementation } \\
\text { of a special policy. }\end{array}$ \\
\hline
\end{tabular}

\subsection{Risk management and economic analysis of financing projects through public private partnership}

The first step in risk management procedure is to identify and to evaluate the relevant risks in financing the project. Afterwards, to reach the desirable result, the risks will be responded properly and based on the forecasted scenarios for the plane incomes and costs, the economic justifications of the plane would be assessed.

\subsection{Principals of the risk identification and evaluation in public private partnership in financing}

The first step in risk management is to define the relevant risks of the project. The process of risk definition in this study is qualitative and performed through interviews and the data collection is done by the means of questionnaire and other similar projects evidences and histories. In order to evaluate each risk and save the relevant amount of risk probability, a domain of scale which is broad enough to distinguish the distances and decrease the ambiguity in interpretation, have been provided. In this way, the distance among the highest, the lowest and the middle level could be distinguished, undoubtedly. Table 3 demonstrates quantitative scales for risk assessment.

\section{Table 3}

Quantitative scales for risk assessment

\begin{tabular}{|c|c|c|c|c|c|}
\hline Level & Very small & Small & Medium & High & Very high \\
\hline Probability & $1 \%-10 \%$ & $10 \%-30 \%$ & $30 \%-50 \%$ & $50 \%-70 \%$ & $70 \%-90 \%$ \\
\hline Scale & 0 & 3 & 4 & 6 & $>8$ \\
\hline
\end{tabular}


According to Table 3, when there is little chance for an incident, we consider zero value or at most one and as we get higher risk for a project, we consider higher values. The scale attribute can be divided into three sub-component and the assigned values can be considered as the number given in Table 4 as follows,

\section{Table 4}

Quantitative scales for risk assessment components

\begin{tabular}{cccccccccccc}
\hline Scale & Very small & \multicolumn{2}{c}{ Small } & \multicolumn{2}{c}{ Medium } & \multicolumn{2}{c}{ High } & \multicolumn{2}{c}{ Very high } \\
\hline Time & 1 & 2 & 3 & 4 & 5 & 6 & 7 & 8 & 9 & 10 \\
Cost & 1 & 2 & 3 & 4 & 5 & 6 & 7 & 8 & 9 & 10 \\
Return & 1 & 2 & 3 & 4 & 5 & 6 & 7 & 8 & 9 & 10 \\
\hline
\end{tabular}

\section{Table 5}

Risk numbers associated with all detected factors based on the negative impact of time, cost and income

\begin{tabular}{|c|c|c|c|}
\hline \multicolumn{2}{|c|}{ Risk factor } & \multicolumn{2}{|c|}{ Risk factor $\quad$ Description } \\
\hline 1 & Excess shareholders & 37 & Bankruptcy of the investors partnership \\
\hline 2 & The absence of investors during the design sections & 38 & Decrease in the amount of the required loan for purchasing real estate \\
\hline 3 & Request for changing outcomes of the project & 39 & Probability of crisis occurrence \\
\hline 4 & Making no rivalry offers for bidders & 40 & Changing in load regulation and limitation in bank services \\
\hline 5 & Weakness of advertisements & 41 & Delay in providing required plans by consultant \\
\hline 6 & Elections and political circumstances & 42 & $\begin{array}{l}\text { Promise for providing house for the landlords in the region of the } \\
\text { scheme }\end{array}$ \\
\hline 7 & Delay in releasing the required lands of the project & 43 & Claims for possessing the lands of the scheme by other people \\
\hline 8 & Release and eliminate of governmental subsidies & 44 & $\begin{array}{l}\text { Delay in completion of the project and not returning the invested assets } \\
\text { in the forecasted time }\end{array}$ \\
\hline 9 & World trade conditions recession & 45 & Delay in planning to provide materials and services for the project \\
\hline 10 & Building slump & 46 & Paying no attention to the clients' desires and needs \\
\hline 11 & Municipalities legislations & 47 & Change in taxation rates \\
\hline 12 & Inflation in construction services and materials price & 48 & Increase in value added taxation \\
\hline 13 & Increase in the land prices in the scheme region & 49 & $\begin{array}{l}\text { Lack of commitment to the project time tables and time responsibilities } \\
\text { by the bidders }\end{array}$ \\
\hline 14 & $\begin{array}{l}\text { Tenant cooperation in slum areas to abuse of the } \\
\text { situation and the lack of cooperation with the authorities }\end{array}$ & 50 & Recession in construction procedure due to the others complaints \\
\hline 15 & Delay in approval of scheme plans by the shareholders & 51 & Delay in getting completion documents \\
\hline 16 & Weakness in selecting investment partnership & 52 & Delay in providing evidence for separation of the properties \\
\hline 17 & $\begin{array}{l}\text { Increase in price of the change in land users by the } \\
\text { municipality }\end{array}$ & 53 & Delay in providing registration documents \\
\hline 18 & Delay in getting construction official allowance & 54 & Increase in the costs of destruction and retaining walls \\
\hline 19 & $\begin{array}{l}\text { Weakness in providing enough cash flow by the } \\
\text { investors }\end{array}$ & 55 & $\begin{array}{l}\text { Increase in the amount of contract price more than } 25 \% \text { of the primary } \\
\text { one }\end{array}$ \\
\hline 20 & $\begin{array}{l}\text { Disagreement of municipality authorities with increase } \\
\text { in construction density in the lands }\end{array}$ & 56 & Avoidance of bidders to sign the supplementary contracts \\
\hline 21 & $\begin{array}{l}\text { Increase in the time required for possessing the } \\
\text { necessary lands }\end{array}$ & 57 & Increase in cost of inspection and consultant of the project due to delays \\
\hline 22 & Breaking the urban construction rules & 58 & Adjustment of payments \\
\hline 23 & Increase in Girder price & 59 & Inherited properties in the region of the scheme \\
\hline 24 & Extra use of second hand bidders & 60 & Disagreement with destruction of properties \\
\hline 25 & Increase in cement price & 61 & Disagreement in destruction of holly places \\
\hline 26 & Weakness in design & 62 & Low speed urban facilities providing \\
\hline 27 & Inability in selling scheme units on time & 63 & Extra cost in urban facilities providing \\
\hline 28 & Unreal time table of the project & 64 & Parallel project implemented near the scheme \\
\hline 29 & Bidder’s Financial problems & 65 & Compensate of delays in payments \\
\hline 30 & Breaking down the investment contracts by investors & 66 & Disability in pre- selling the scheme unities \\
\hline 31 & Shortage in investors' participation & 67 & Decrease in worth of the lands in the region of the scheme \\
\hline 32 & Being unqualified for receiving banks' loan & 68 & Decrease in worth amount of the properties \\
\hline 33 & Lack of profitability of the project for the bidders & 69 & $\begin{array}{l}\text { Collaborative of landlords to increase the worth of the lands in the } \\
\text { scheme region }\end{array}$ \\
\hline 34 & Lack of project profitability for the shareholders & 70 & Interference of the relevant authorities \\
\hline 35 & Increase in bank interest rate & 71 & No allocation of slum areas subsidies \\
\hline 36 & Bankruptcy of the investors partnership & & $\begin{array}{l}\text { Recession in commercial units sale because of the disability of the } \\
\text { recession or competitive conditions }\end{array}$ \\
\hline
\end{tabular}

\subsection{The risk assessment procedure}

We detect all different risk components associated with the project, separately and using the impact of each risk procedure one may calculate the overall risk measure as follows, 
$R=P \times I \times \prod_{i=1}^{n} I_{i}$,

where $P, I$ are probability and risk influence, $I_{i}$ is the risk influence for $i^{\text {th }}$ component with $i=1, \cdots n$. Since there are three components in our case study therefore we have $n=3$. In other word, $\boldsymbol{I}_{\mathbf{1}}$ is the multiplier of the time influence rectifier, $\boldsymbol{I}_{\mathbf{2}}$ is the multiplier of the management ability rectifier and $\boldsymbol{I}_{\mathbf{3}}$ is the multiplier of amount of risk familiarity rectifier. For the case study of our proposed model, we have detected 71 risk factors, which are summarized in Table 5.

Table 6 summarizes the numbers associated with all three factors of time, cost and income for all 71 factors. Note that risk items denoted by R\# are the same as the ones shown in the previous table. The items show risk factors with negative impacts of time, cost and income.

Table 6

Risk numbers associated with all detected factors based on the negative impact of time, cost and income

\begin{tabular}{|c|c|c|c|c|c|c|c|c|c|c|c|c|c|c|c|c|c|c|c|c|c|}
\hline R\# & $\mathrm{T}$ & $\mathrm{C}$ & I & $\operatorname{Pr}$ & RI & MTI & MMA & MRF & $\mathrm{R}$ & RP & R\# & $\mathrm{T}$ & $\mathrm{C}$ & I & $\operatorname{Pr}$ & RI & MTI & MMA & MRF & $\mathrm{R}$ & $\mathrm{RP}$ \\
\hline 1 & $\mathrm{M}$ & & & 8 & 6 & 0.8 & 1 & 1 & 38.4 & 20 & 37 & & & $\mathrm{M}$ & 3 & 5 & 0.9 & 1.2 & 1 & 16.2 & 56 \\
\hline 2 & M & & & 7 & 5 & 0.8 & 0.9 & 1 & 25.2 & 39 & 38 & VL & & & 4 & 1 & 1 & 1 & 1 & 4.0 & 69 \\
\hline 3 & & M & & 5 & 4 & 1.1 & 1.1 & 0.9 & 21.8 & 46 & 39 & M & VL & & 3 & 5 & 0.9 & 1 & 1 & 13.5 & 60 \\
\hline 4 & & $\mathrm{~L}$ & & 8 & 3 & 1 & 1 & 0.9 & 21.6 & 47 & 40 & M & & & 5 & 5 & 1 & 1 & 1 & 25.0 & 40 \\
\hline 5 & & & M & 8 & 5 & 1.1 & 0.9 & 0.8 & 31.7 & 26 & 41 & & & VL & 3 & 2 & 0.8 & 0.9 & 0.8 & 3.5 & 71 \\
\hline 6 & & & $\mathrm{~L}$ & 5 & 3 & 0.8 & 1.2 & 1.2 & 17.3 & 54 & 42 & VH & & & 6 & 9 & 0.9 & 1 & 0.9 & 43.7 & 10 \\
\hline 7 & & H & & 8 & 8 & 1.1 & 1 & 1.1 & 77.4 & 1 & 43 & & $\mathrm{H}$ & $\mathrm{L}$ & 5 & 1 & 1.2 & 0.9 & 1 & 5.4 & 68 \\
\hline 8 & M & $\mathbf{H}$ & $\mathbf{H}$ & 8 & 6 & 1 & 1.2 & 1 & 57.6 & 5 & 44 & L & M & & 4 & 1 & 1 & 1 & 1 & 4.0 & 70 \\
\hline 9 & & & $\mathrm{~L}$ & 6 & 3 & 0.8 & 1.2 & 0.8 & 13.8 & 59 & 45 & & $\mathrm{~L}$ & M & 4 & 5 & 1.1 & 0.9 & 0.9 & 17.8 & 52 \\
\hline 10 & & & $\mathrm{M}$ & 7 & 5 & 1.2 & 1.2 & 0.8 & 40.3 & 14 & 46 & & & & 3 & 2 & 1.1 & 1.2 & 1.2 & 9.5 & 64 \\
\hline 11 & M & L & & 5 & 4 & 0.8 & 1.2 & 1.2 & 23.0 & 44 & 47 & & $\mathrm{~L}$ & & 5 & 2 & 1.1 & 1 & 0.9 & 9.9 & 63 \\
\hline 12 & & $\mathrm{H}$ & & 6 & 7 & 1 & 1 & 1 & 42.0 & 13 & 48 & & $\mathrm{~L}$ & & 6 & 6 & 1.1 & 0.9 & 1 & 35.6 & 23 \\
\hline 13 & & VH & & 5 & 9 & 0.8 & 1 & 1 & 36.0 & 22 & 49 & $\mathrm{~L}$ & $\mathrm{M}$ & & 5 & 4 & 1 & 1 & 1 & 20.0 & 49 \\
\hline 14 & & VH & H & 6 & 9 & 0.8 & 1.2 & 0.9 & 46.7 & 8 & 50 & $\mathrm{~L}$ & & & 6 & 4 & 1.2 & 1 & 1 & 28.8 & 30 \\
\hline 15 & VH & $\mathrm{M}$ & & 5 & 9 & 1.1 & 0.8 & 0.8 & 31.7 & 27 & 51 & $\mathrm{~L}$ & & & 6 & 3 & $\begin{array}{l}1.2 \\
1.2\end{array}$ & $\begin{array}{c}1 \\
0.9\end{array}$ & $\begin{array}{c}1 \\
0.9\end{array}$ & $\begin{array}{l}20.0 \\
17.5\end{array}$ & 53 \\
\hline 16 & $\mathbf{H}$ & $\mathbf{H}$ & & 6 & 8 & 1 & 1 & 1 & 48.0 & 6 & 52 & $\mathrm{~L}$ & & & 6 & 4 & 1.2 & 0.9 & 0.8 & 20.7 & 48 \\
\hline 17 & $\mathrm{H}$ & M & & 7 & 7 & 0.8 & 1 & 1 & 39.2 & 16 & 53 & & & & 7 & 6 & 0.8 & 1 & 1 & 33.6 & 24 \\
\hline 18 & M & M & & 4 & 2 & 0.8 & 0.9 & 0.9 & 5.2 & 67 & 54 & L & $\mathrm{M}$ & & 6 & 3 & 1.1 & 1 & 1 & 19.8 & 51 \\
\hline 19 & VH & VH & & 7 & 10 & 1.1 & 0.8 & 1 & 61.6 & 4 & 55 & M & & & 4 & 5 & 1.2 & 1.1 & 1 & 26.4 & 36 \\
\hline 20 & & & $\mathrm{H}$ & 5 & 7 & 0.8 & 1.2 & 1 & 33.6 & 25 & 56 & L & & & 5 & 3 & 1.1 & 1 & 1 & 16.5 & 55 \\
\hline 21 & VH & M & & 6 & 8 & 0.8 & 0.8 & 0.9 & 27.6 & 33 & 57 & & L & & 6 & 5 & 1.1 & 0.9 & 1 & 29.7 & 28 \\
\hline 22 & $\mathrm{M}$ & $\mathrm{L}$ & $\mathrm{H}$ & 4 & 6 & 1 & 1 & 1 & 24.0 & 42 & 58 & VH & $\mathrm{M}$ & & 5 & 8 & 0.8 & 1.1 & 1.1 & 38.7 & 17 \\
\hline 23 & & $\mathrm{~L}$ & $\mathrm{H}$ & 6 & 8 & 0.9 & 1 & 1 & 43.2 & 11 & 59 & $\mathrm{H}$ & L & & 7 & 7 & 0.8 & $\begin{array}{c}1.1 \\
1\end{array}$ & $\begin{array}{c}1.1 \\
1\end{array}$ & 39.2 & 16 \\
\hline 24 & L & $\mathrm{L}$ & & 6 & 2 & 1.2 & 1 & 0.9 & 13.0 & 61 & 60 & VH & & & 2 & 9 & 0.8 & 1.2 & 0.5 & 8.64 & 66 \\
\hline 25 & & M & M & 6 & 2 & 1 & 1 & 1 & 12.0 & 62 & 61 & $\mathrm{H}$ & & & 5 & 7 & 0.8 & 1 & 1 & 28.0 & 32 \\
\hline 26 & M & M & $\mathrm{M}$ & 5 & 6 & 1 & 0.8 & 1 & 24.0 & 43 & 62 & & & & 4 & 3 & $\begin{array}{l}0.0 \\
1.2\end{array}$ & $\begin{array}{l}1 \\
1\end{array}$ & $\begin{array}{l}1 \\
1\end{array}$ & $\begin{array}{l}20.0 \\
14.4\end{array}$ & 57 \\
\hline 27 & & & H & 6 & 8 & 1.2 & 1.1 & 1 & 63.4 & 3 & 63 & & L & L & 3 & 3 & 1 & 1 & 1 & 9.0 & 65 \\
\hline 28 & VH & H & & 6 & 9 & 1.2 & 0.8 & 0.9 & 46.7 & 9 & 64 & & & & 5 & 6 & 1.1 & 0.9 & 0.9 & 26.7 & 35 \\
\hline 29 & M & & & 5 & 6 & 1 & 0.9 & 1 & 27.0 & 34 & 65 & H & $\mathbf{M}$ & H & 5 & 8 & 1.2 & 1 & 1 & 48.0 & 7 \\
\hline 30 & VH & M & & 4 & 8 & 1 & 1.2 & 1 & 38.4 & 19 & 66 & & $\mathrm{M}$ & $\mathrm{H}$ & 6 & 7 & 0.8 & 0.8 & 0.9 & 24.2 & 41 \\
\hline 31 & & & L & 6 & 4 & 0.9 & 0.8 & 0.8 & 13.8 & 59 & 67 & & & $\mathrm{H}$ & 5 & 7 & 1.2 & 0.9 & 1 & 37.8 & 20 \\
\hline 32 & $\mathrm{Hi}$ & & & 4 & 7 & 1 & 1 & 1 & 28.0 & 32 & 68 & M & & & 7 & 7 & 0.8 & 1.1 & 1 & 43.1 & 12 \\
\hline 33 & $\mathrm{M}$ & M & & 5 & 6 & 1.1 & 0.8 & 1 & 26.4 & 37 & 69 & M & $\mathrm{H}$ & & 4 & 5 & 1 & 1 & 1 & 20.0 & 50 \\
\hline 34 & $\mathrm{M}$ & $\mathrm{M}$ & $\mathrm{Hi}$ & 5 & 6 & $\begin{array}{l}1.1 \\
1.1\end{array}$ & $\begin{array}{l}0.0 \\
1.1\end{array}$ & $\begin{array}{l}1 \\
1\end{array}$ & $\begin{array}{l}20.4 \\
36.3\end{array}$ & 21 & 70 & $\mathrm{M}$ & & M & $\begin{array}{l}4 \\
3\end{array}$ & 6 & $\begin{array}{l}1 \\
1\end{array}$ & $\begin{array}{c}1 \\
1.2\end{array}$ & $\begin{array}{l}1 \\
1.2\end{array}$ & 25.9 & 38 \\
\hline 35 & & & $\mathrm{M}$ & 4 & 5 & 1 & 1.1 & 1 & 22.0 & 45 & 71 & M & & VH & 8 & 9 & 0.8 & 1.2 & 1 & 69.1 & 2 \\
\hline 36 & VH & & & 3 & 9 & 1.1 & 1 & 1 & 29.7 & 29 & & & & & & & & & & & \\
\hline
\end{tabular}

R\#: Risk item, C:Cost, I:Income, T:Time, H:High, M:Medum, L:Low, VH: Very high, RI: Risk Influence, MTI: Multiplier of time influence, MMA: multiplier of the management ability, MRF: Multiplier of amount of risk familiarity, RP: Risk priority, Bold rows represent items with relatively higher degree of risks

As we can observe "Delay in releasing the required lands of the project" has been considered as an item with the most negative impact on the outcome of the project followed by " Recession in commercial units sale because of the disability of the recession or competitive conditions". These are the most unfavorable incidents that could impact the financial performance of the project. There are many evidences to believe that housing market in Iran has cyclical trend and we may expect a jump in housing price almost every four years. There are other some evidences that show the housing pricing index in Iran also fluctuate with global housing price change. There are also some risk factors with positive impacts on the outcome of the project, which are summarized in Table 7. As we can observe from Table 7, there are many 27 factors, which could positively influence the financial outcome of such projects. For instance, the municipality could change its regulation by easing some rules and this could increase the profitability of a project. 
Table 7

Risk numbers associated with all detected factors based on the negative impact of time, cost and income

\begin{tabular}{|c|c|c|c|}
\hline \multicolumn{2}{|c|}{ Risk factor Description } & \multicolumn{2}{|c|}{ Risk factor $\quad$ Description } \\
\hline 1 & Municipality legislations & 15 & Increase in properties worth \\
\hline 2 & Banks services in slum areas & 16 & Decrease in bank interest rate \\
\hline 3 & Buyers enthusiastic to purchase and invest in the renewal schemes & 17 & Decrease in inflation rate \\
\hline 4 & Improvement in economic conditions & 18 & Decrease in man power services due to recession \\
\hline 5 & Good ability of investors to finance the project & 19 & $\begin{array}{l}\text { Decrease in construction materials prices due to } \\
\text { recession }\end{array}$ \\
\hline 6 & $\begin{array}{l}\text { Decrease in the required construction time by application of mass housing } \\
\text { methods }\end{array}$ & 20 & Discounts on cash paying \\
\hline 7 & Industrially construction and decrease in construction time & 21 & On credit purchasing \\
\hline 8 & Existence of variety fields of investment among the buyers & 22 & Time sharing selling \\
\hline 9 & Discounts on issuing construction documents in slum areas & 23 & Allowance for Increase in construction density \\
\hline 10 & Partnership with the region of the scheme landlords in the profit of the project & 24 & Decrease in construction penalties prices \\
\hline 11 & Increase in the scheme budget & 25 & Possibility of penalties payment by installment \\
\hline 12 & Possibility of partnership with foreign bidders & 26 & Taking advantage of seasonal and periodical discounts \\
\hline 13 & Possibility of receiving loans from foreign banks & 27 & Discounts in cash payment of construction allowance \\
\hline 14 & Possibility of receiving governmental subsidies in slum areas & & \\
\hline
\end{tabular}

Table 8 shows the relative importance of these factors. As we can see any increase in the scheme budget could significantly increase the buying power and could facilitate the performance of the project. At the same time, when a mass production plan is scheduled, many infrastructure can be used over and over which could reduce the total amount of investment.

\section{Table 8}

Risk numbers associated with all detected factors based on the negative impact of time, cost and income

\begin{tabular}{|c|c|c|c|c|c|c|c|c|c|c|c|c|c|c|c|c|c|c|c|c|c|}
\hline $\mathrm{R \#}$ & $\mathrm{T}$ & $\mathrm{C}$ & I & $\mathrm{Pr}$ & RI & MTI & MMA & MRF & $\mathrm{R}$ & $\mathrm{RP}$ & R\# & $\mathrm{T}$ & $\mathrm{C}$ & I & $\mathrm{Pr}$ & RI & MTI & MMA & MRF & $\mathrm{R}$ & $\mathrm{RP}$ \\
\hline 1 & & $\mathrm{~L}$ & $\mathrm{~L}$ & 6 & 4 & 1 & 1 & 1 & 24 & 15 & 15 & & & $\mathbf{H}$ & 6 & 7 & 1.2 & 0.8 & 0.8 & 32.256 & 8 \\
\hline 2 & $\mathbf{L}$ & & & 8 & 4 & 1.1 & 1 & 1 & 35.2 & 7 & 16 & & M & & 4 & 6 & 1 & 0.8 & 0.8 & 15.36 & 20 \\
\hline 3 & $\mathrm{~L}$ & & & 6 & 4 & 1.1 & 1 & 1 & 26.4 & 14 & 17 & & $\mathrm{H}$ & & 4 & 7 & 1 & 0.9 & 0.8 & 20.16 & 18 \\
\hline 4 & & & & 6 & 3 & 1 & 0.8 & 0.8 & 11.52 & 23 & 18 & & M & & 5 & 5 & 1 & 1.2 & 1 & 30 & 9 \\
\hline 5 & H & & & 6 & 8 & 1.2 & 1 & 1 & 57.6 & 3 & 19 & & M & & 5 & 5 & 1 & 1.2 & 1 & 30 & 10 \\
\hline 6 & $\mathbf{H}$ & $\mathbf{L}$ & $\mathbf{L}$ & 7 & 7 & 1.2 & 1.1 & 1 & 64.68 & 2 & 20 & & $\mathrm{~L}$ & & 6 & 4 & 1 & 1.2 & 1 & 28.8 & 10 \\
\hline 7 & $\mathrm{H}$ & $\mathrm{L}$ & $\mathrm{L}$ & 2 & 7 & 1 & 1 & 1 & 14 & 21 & 21 & $\mathbf{M}$ & $\mathbf{L}$ & & 7 & 5 & 1.1 & 1 & 1 & 38.5 & 5 \\
\hline 8 & & & & 5 & 4 & 1.1 & 1 & 0.8 & 17.6 & 18 & 22 & & $\mathbf{L}$ & H & 7 & 5 & 1 & 1.1 & 1 & 38.5 & 6 \\
\hline 9 & & M & M & 7 & 6 & 0.8 & 0.8 & 0.8 & 21.504 & 15 & 23 & & M & & 5 & 6 & 0.8 & 1.2 & 1 & 28.8 & 11 \\
\hline 10 & H & & & 6 & 7 & 1 & 1 & 0.9 & 37.8 & 4 & 24 & & $\mathrm{M}$ & & 4 & 5 & 0.8 & 0.8 & 0.8 & 10.24 & 23 \\
\hline 11 & VH & & & 6 & 10 & 1 & 1.1 & 1.2 & 79.2 & 1 & 25 & & $\mathrm{~L}$ & & 4 & 3 & 0.8 & 1 & 1 & 9.6 & 24 \\
\hline 12 & $\mathrm{~L}$ & & & 2 & 3 & 0.9 & 0.8 & 0.8 & 3.456 & 27 & 26 & & $\mathrm{~L}$ & & 7 & 3 & 1 & 1 & 1 & 21 & 16 \\
\hline 13 & & & & 2 & 5 & 0.8 & 1 & 1 & 8 & 26 & 27 & & $\mathrm{~L}$ & & 8 & 3 & 0.8 & 1 & 0.8 & 15.36 & 19 \\
\hline 14 & & & M & 5 & 6 & 1.2 & 1 & 0.8 & 28.8 & 13 & & & & & & & & & & & \\
\hline
\end{tabular}

R\#: Risk item, C:Cost, I:Income, T:Time, H:High, M:Medum, L:Low, VH: Very high, RI: Risk Influence, MTI: Multiplier of time influence, MMA: multiplier of the management ability, MRF: Multiplier of amount of risk familiarity, RP: Risk priority, Bold rows represent items with relatively higher degree of risks

After identifying the relevant risks, due to the nature of the research, it is necessary to define the risks influences on the profitability and economic return indexes. What is considered as the relationship between project risk management and economic returns would be the identification and forecasting scenarios of incomes acquired from purchasing the scheme units and the probable effects of the threats and opportunities arisen from negative and positive risks. These risks affect the main indexes of the project including time, costs and the expected incomes. It would be possible to reach the principal aims of the project comprising of decrease in project time, decrease in project cost and maximizing the scheme incomes by application of the project risk management methods. In the following, after economic analysis of the scheme, based on three scenarios of sale including optimistic, most probable and pessimistic, the economic indexed will be probed under the risks influences.

\subsection{Economic analysis of the revitalization of Saheb Alzaman Boulevard}

Sahaeb Alzaman Boulevard renewal project is being constructed in an area of 50000 meter square near the one of the Mashhad famous regions entitled Shohada Square and near the Holly Shrine. The 
under construction area of the plan is about 50,000 square meter including 14 blocks of residential, commercial and official units. The construction of the scheme is implemented by a group of mass housing firms and the project management is done by the $8^{\text {th }}$ Anbohsazan firm and the investment is also done by private section, semi public organization, the collaboration of project bidders and the municipality of Mashhad. The investment condition of the investment is as follows: $65 \%$ of the total costs will be provided by private investors which is allocated for the lands release, construction allowances documents and services, 35\% of the total costs which is allocated for construction costs which the $70 \%$ of them are supplied by one the semi-governmental organizations (Military welfare organization, SATA) and $30 \%$ of it is supplied by a collaboration of bidder companies $\left(8^{\text {th }}\right.$ Anbohsazan). The costs of the project have been forecasted based on a 48 months time table and the costs have been also updated based on the inflation rate and regarding the date of expenditure in the time table. The average inflation rate for each month is considered approximately $2 \%$ in relation to preliminary forecasted cost. Based on the agreement among the scheme shareholders, $17.5 \%$ of the total incomes of the scheme will be allocated to municipality of Mashhad for the construction permits and changes in land using format. In addition, 3.1\% of the incomes will be allocated to $8^{\text {th }}$ Anbohsazan firm as the project management reward. Table 9 shows the cost structure of the plans in terms of different factors.

\section{Table 9}

Cost structure of the proposed plan in terms of million Rials

\begin{tabular}{lccc}
\hline Total monthly costs & Up to dated costs & Future integrated and updated costs & Integrated cash flow \\
\hline 346,384 & 441,498 & 441,498 & 441,498 \\
\hline
\end{tabular}

\subsection{Forecast of the scheme units sale}

Regarding the interviews conducted with estate specialists and realtors in the regions in which the scheme is under construction and the preliminary forecasts of the region sale prices, 3 scenarios of sale and income for each square meter of the scheme have been defined, which are summarized in Table 10. However, considering the constriction and revitalization activities in the scheme region, the prices seem to develop more than the forecasted worth and even higher than the optimistic condition. These scenarios have been defined based on taking advantage of opportunities and avoiding the threats arisen from defined risks.

\section{Table 10}

Sales Scheme under different scenarios

\begin{tabular}{|c|c|c|c|c|c|c|c|c|}
\hline Row & Beta & RUP & CUP & OUP & IRU & ICU & IOU & $\mathrm{TI}$ \\
\hline 1 & pessimistic & 13 & 55 & 25 & 305,656 & $1,662,650$ & 176,875 & $2,145,181$ \\
\hline 2 & Most probable & 16 & 70 & 30 & 376,192 & $2,116,100$ & 212,250 & $2,704,542$ \\
\hline 3 & Most optimistic & 18 & 80 & 33 & 423,216 & $2,418,400$ & 233,475 & $3,075,091$ \\
\hline 4 & average & 16 & 68 & 29 & 368,355 & $2,065,717$ & 207,533 & $2,641,605$ \\
\hline 5 & Standard failure & 3 & 13 & 4 & 59,171 & 380,386 & 28,593 & 468,150 \\
\hline
\end{tabular}

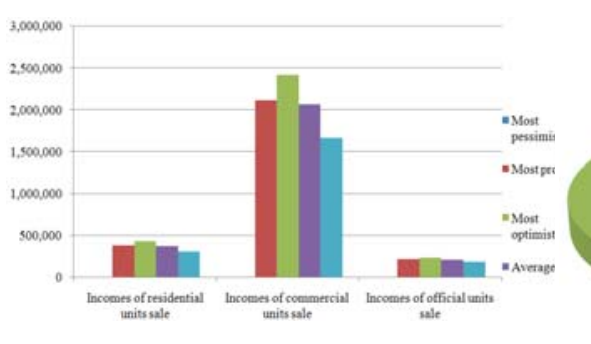

Fig. 1. Forecasted incomes of scheme units

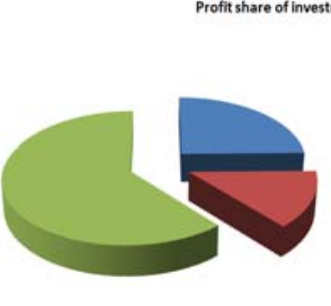

Fig. 2. profit shares of stockholders

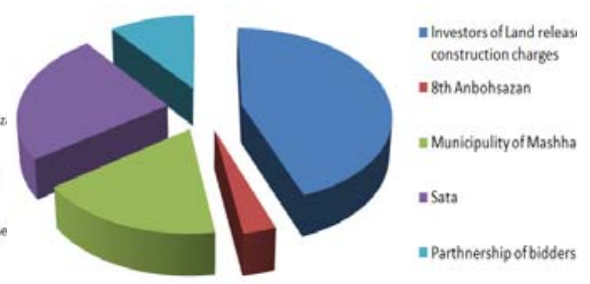

Fig. 3. Share of sale income 
Fig. 1 shows the income based on different scenarios in terms of the most optimistic, most probable, the most pessimistic and the average figures. Regarding what the Fig. 1 reveals, a majority of scheme incomes are provided by sale of the commercial units. Based on what forecasted through conducted interviews with the scheme experts, the difference between the optimistic and pessimistic incomes is really considerable which is making crucial negative risks and threats through the desirable incomes of the scheme and even whole the project.

\subsection{Discounting rate of investment and real profit forecast}

One of the most important issues of evaluating a project is discounting rate, especially in countries such as Iran where the inflation rate is usually in two digit numbers. In such cases, the net present value of a project is normally considered to $18 \%$. It should be mentioned that the aforementioned discount rate is an average amount of the discount rate in a period of four years which is divided equally into months in this period of time. In order to calculate the net present values(NPV), the following formula is utilized.

$$
P_{v}=\sum_{1}^{n}\left(F_{v}\right)_{t}\left[\frac{1}{\left(1+i_{e}\right)^{t}}\right],
$$

where $P_{v}$ is the present value, $F_{v}$ is the future value in time $\mathrm{t}$ and $i_{e}$ is the discount rate. Table 11 shows the necessary information needed for net present value analysis.

Table 11

The input information for the calculation of net present value

\begin{tabular}{cccccccc}
\hline M & F & CFC & NPV1 & INPV & LRC & NPV2 & NPV3 \\
\hline 1 & 346 & 346 & 346 & 346 & 30,000 & 29,557 & 29,557 \\
2 & 1,749 & 2,096 & 1,723 & 2,070 & 16,000 & 15,534 & 45,091 \\
3 & 1,767 & 3,862 & 1,715 & 3,785 & 40,000 & 38,278 & 83,368 \\
4 & 2,497 & 6,360 & 2,390 & 6,175 & 32,000 & 30,189 & 113,557 \\
$\vdots$ & & & & & & 0 & 186,559 \\
48 & 15,276 & 441,498 & 8,959 & 314,323 & 0 & 186,559 & \\
total & 441,498 & & 314,323 & & 200,000 & 13,441
\end{tabular}

M: Months, F: Future cost, CFC: Cash flow of construction costs, NPV1: NPV of updated cost (Million Rials), INPV: Integrated NPV, LRC: Land release costs (Million Rials), NPV2: NPV of land release costs (Million Rials), NPV3: NPV of integrated costs of land release (Million Rials)

This amount arisen from the discount in investments which means that if the investors invested their assets in banks or riskless projects, they got profit at least this amount of money without any risks. In addition, these discounts will be added to the other costs of the project as a decrease of the money value to justify the real profit. The discounting costs of investment in the land release will be added to itself and the discount costs of the investment in construction will be also added to itself.

Table 12

The real income of the scheme sales

\begin{tabular}{cccccccc}
\hline LU & NA & GIS & MPC & 8 AF & NI & DI & NPS \\
\hline Residential & 23,512 & 282,144 & 49,375 & 8,746 & 224,022 & 24,275 & 199,747 \\
Commercial & 30,230 & $1,058,050$ & 185,159 & 32,800 & 840,092 & 91,030 & 749,062 \\
Office & 7,075 & 137,963 & 24,143 & 4,277 & 109,542 & 11,870 & 97,672 \\
\hline Total & & $1,478,157$ & 258,677 & 45,823 & $1,173,656$ & 127,175 & $1,046,481$ \\
\hline
\end{tabular}

LU: Land use, NA: Net area (square meter), GIS: Growing income of sale (Million Rials), MPC: Municipality partnership costs(Million Rilas), 8AF: 8th Anbohsazan fees(Million Rials), NI: Net incomes (Million Rials), DI: Discounts of investment(Million Rials), NPS: Net profit from sale(Million Rials)

\subsection{Planning for responding the risks}

One of the main goals of this research is to respond the existence risks in the financing procedure and to increase the profitability of the scheme besides the attraction of the investment in these projects. Such increase not only accelerates the construction rate but also enriches the urban workability 
indexes. To reach this aim, proper strategies should be devised to respond the risks including: Avoidance, mitigation, transfer (allocation), Exploit (instead of avoidance), Enhancement, acceptance and sharing (instead of transfer). In order to take most of the positive risks leading to opportunities, such risks should be responded properly. The suitable responses to negative risks needed to avoid the threats. Table 13 summarizes the suggested actions for the most important negative risk items given in Table 6.

\section{Table 13}

The necessary suggested actions for the most important negative risk factors

\begin{tabular}{|c|c|c|c|c|c|c|c|}
\hline $\mathrm{R} \#$ & Risk resource & $\begin{array}{l}\text { Risk } \\
\text { score }\end{array}$ & $\begin{array}{c}\text { Risk } \\
\text { priority }\end{array}$ & $\begin{array}{c}\text { Responding } \\
\text { strategies }\end{array}$ & Risk responding plan & $\begin{array}{c}\text { Proper time of } \\
\text { responding }\end{array}$ & $\begin{array}{l}\text { Responsible } \\
\text { organization }\end{array}$ \\
\hline 7 & $\begin{array}{l}\text { Delay in } \\
\text { releasing the } \\
\text { required lands of } \\
\text { the project }\end{array}$ & 77.4 & 1 & $\begin{array}{l}\text { Transferring, } \\
\text { sharing, } \\
\text { acceptance }\end{array}$ & $\begin{array}{l}\text { Transferring the responsibility of purchasing } \\
\text { and releasing required lands of the scheme to } \\
\text { a selected group from municipality of } \\
\text { Mashhad who have enough authority and } \\
\text { ability for negotiation }\end{array}$ & $\begin{array}{l}\text { First half time } \\
\text { of the project }\end{array}$ & $\begin{array}{l}\text { Municipality of } \\
\text { Mashhad, } 8^{\text {th }} \\
\text { Anbohsazan }\end{array}$ \\
\hline 71 & $\begin{array}{l}\text { Recession in } \\
\text { commercial units } \\
\text { sale because of } \\
\text { the disability of } \\
\text { the recession or } \\
\text { competitive } \\
\text { conditions }\end{array}$ & 69.1 & 2 & $\begin{array}{l}\text { Transferring, } \\
\text { Sharing } \\
\text { Acceptance }\end{array}$ & $\begin{array}{l}\text { Pre-selling some of the scheme units based } \\
\text { on the most probable prices and forming } \\
\text { partnership to sell units }\end{array}$ & $\begin{array}{l}\text { Preliminarily } \\
3 / 10 \text { time of } \\
\text { the project }\end{array}$ & $\begin{array}{l}\text { Municipality of } \\
\text { Mashhad, } 8^{\text {th }} \\
\text { Anbohsazan }\end{array}$ \\
\hline 27 & $\begin{array}{l}\text { Inability in } \\
\text { selling scheme } \\
\text { units on time }\end{array}$ & 63.4 & 3 & $\begin{array}{l}\text { Sharing, } \\
\text { Mitigation }\end{array}$ & $\begin{array}{l}\text { Planning to advertise the units to be sold on } \\
\text { time or on installments }\end{array}$ & $\begin{array}{l}\text { Second half } \\
\text { time of the } \\
\text { project }\end{array}$ & $8^{\text {th }}$ Anbohsazan \\
\hline 19 & $\begin{array}{l}\text { Weakness in } \\
\text { providing } \\
\text { enough cash } \\
\text { flow by the } \\
\text { investors }\end{array}$ & 61.6 & 4 & $\begin{array}{l}\text { Sharing, } \\
\text { Mitigation }\end{array}$ & $\begin{array}{l}\text { Planning to receive bank loads in the period } \\
\text { of time that there are problems in financing } \\
\text { the project, Devising mechanisms to make } \\
\text { investors bond to their financial } \\
\text { responsibilities }\end{array}$ & $\begin{array}{l}\text { All the time of } \\
\text { the project }\end{array}$ & $8^{\text {th }}$ Anbohsazan \\
\hline 8 & $\begin{array}{l}\text { Release and } \\
\text { eliminate of } \\
\text { governmental } \\
\text { subsidies }\end{array}$ & 57.6 & 5 & $\begin{array}{l}\text { Transferring, } \\
\text { Acceptance }\end{array}$ & $\begin{array}{l}\text { Forecasting the needed materials and services } \\
\text { to be contracted as fixed prices. Payment in } \\
\text { advance to bidders to buy their required } \\
\text { materials in the same time of signing } \\
\text { contracts. }\end{array}$ & $\begin{array}{l}\text { All the time of } \\
\text { the project }\end{array}$ & $\begin{array}{l}8^{\text {th }} \text { Anbohsazan, } \\
\text { Partnership of } \\
\text { Bidder companies }\end{array}$ \\
\hline 16 & $\begin{array}{l}\text { Weakness in } \\
\text { selecting } \\
\text { investment } \\
\text { partnership }\end{array}$ & 48 & 6 & avoidance & $\begin{array}{l}\text { Getting enough guarantees from financial } \\
\text { partners and having enough cognition of } \\
\text { them }\end{array}$ & $\begin{array}{l}\text { Preliminarily } \\
1 / 10 \text { time of } \\
\text { the project }\end{array}$ & $8^{\text {th }}$ Anbohsazan \\
\hline 65 & $\begin{array}{l}\text { Decrease in } \\
\text { worth of the } \\
\text { lands in the } \\
\text { region of the } \\
\text { scheme }\end{array}$ & 48 & 7 & $\begin{array}{l}\text { Sharing, } \\
\text { Mitigation }\end{array}$ & $\begin{array}{l}\text { Advertising for units sale, agreement with } \\
\text { investors to give the units instead the } \\
\text { invested monies based on the preliminarily } \\
\text { agreed prices }\end{array}$ & $\begin{array}{l}\text { Last } 3 / 10 \text { time } \\
\text { of the project }\end{array}$ & $\begin{array}{l}8^{\text {th }} \text { Anbohsazan, } \\
\text { Partnership of } \\
\text { bidder companies, } \\
\text { Municipality of } \\
\text { Mashhad, Sata }\end{array}$ \\
\hline 14 & $\begin{array}{l}\text { Tenant } \\
\text { cooperation in } \\
\text { slum areas to } \\
\text { abuse of the } \\
\text { situation and not } \\
\text { to cooperate with } \\
\text { the authorities }\end{array}$ & 46.7 & 8 & $\begin{array}{l}\text { Avoidance, } \\
\text { Transferring }\end{array}$ & $\begin{array}{l}\text { Planning to destroy any constructed building } \\
\text { in the released lands to lessen the lands price }\end{array}$ & $\begin{array}{l}\text { First half of } \\
\text { time of the } \\
\text { project }\end{array}$ & $\begin{array}{l}\text { Municipality of } \\
\text { Mashhad, } 8^{\text {th }} \\
\text { Anbohsazan }\end{array}$ \\
\hline 28 & $\begin{array}{l}\text { Unreal time table } \\
\text { of the project }\end{array}$ & 46.7 & 9 & $\begin{array}{l}\text { Mitigation, } \\
\text { Acceptance }\end{array}$ & $\begin{array}{l}\text { Pre- defined Time table of the project and } \\
\text { defining fines for delays in completion the } \\
\text { responsibilities }\end{array}$ & $\begin{array}{l}\text { All the time of } \\
\text { the project }\end{array}$ & $\begin{array}{l}8^{\text {th }} \text { Anbohsazan, } \\
\text { Partnership of } \\
\text { bidder companies }\end{array}$ \\
\hline 42 & $\begin{array}{l}\text { Claims for } \\
\text { possessing the } \\
\text { lands of the } \\
\text { scheme by other } \\
\text { people }\end{array}$ & 43.7 & 10 & $\begin{array}{l}\text { Avoidance, } \\
\text { Transferring }\end{array}$ & $\begin{array}{l}\text { Gathering official information about the } \\
\text { scheme region properties and public } \\
\text { declaration of them }\end{array}$ & $\begin{array}{l}\text { First half time } \\
\text { of the project }\end{array}$ & $\begin{array}{l}8^{\text {th }} \text { Anbohsazan, } \\
\text { Partnership of } \\
\text { bidder companies }\end{array}$ \\
\hline
\end{tabular}

As we can see from Table 13, land release is on top of the list of our risk assessment and our suggestion is to Transfer the responsibility of purchasing and releasing required lands of the scheme to a selected group from municipality of Mashhad who have enough authority and ability for negotiation. The second issue on our list was the recession in commercial units' sale because of the disability of the recession or competitive conditions and we recommend to create some especial offer for the project components so that when the project is finished such a problem would not appear. 
There are other suggestions that the reader could follow from the table. We have also recommended some guidelines to take advantage of positive risks, which are summarized in Table 14.

Table 14

The necessary suggested actions for the most important positive risk factors

\begin{tabular}{|c|c|c|c|c|c|c|c|}
\hline R\# & Risk resource & $\begin{array}{l}\text { Risk } \\
\text { score }\end{array}$ & $\begin{array}{l}\text { Risk } \\
\text { priority }\end{array}$ & $\begin{array}{l}\text { Responding } \\
\text { strategies }\end{array}$ & Risk responding plan & $\begin{array}{l}\text { Proper time } \\
\text { of } \\
\text { responding }\end{array}$ & $\begin{array}{l}\text { Responsible } \\
\text { organization }\end{array}$ \\
\hline 11 & $\begin{array}{l}\text { Increase in the } \\
\text { budget }\end{array}$ & 79.2 & 1 & Enrichment & $\begin{array}{l}\text { Encouraging investors to on time financing } \\
\text { and making use of daily profit counting } \\
\text { system }\end{array}$ & $\begin{array}{l}\text { All the time } \\
\text { of the project }\end{array}$ & $8^{\text {th }}$ Anbohsazan \\
\hline 6 & $\begin{array}{l}\text { Decrease in the } \\
\text { required } \\
\text { construction } \\
\text { time by } \\
\text { application of } \\
\text { mass housing }\end{array}$ & 64.68 & 2 & exploit & $\begin{array}{l}\text { Using novel technologies in construction, } \\
\text { architectural plan and facade of buildings } \\
\text { which are workable and having reasonable } \\
\text { good prices }\end{array}$ & $\begin{array}{l}\text { All the time } \\
\text { of the project }\end{array}$ & $\begin{array}{l}8^{\text {th }} \text { Anbohsazan, } \\
\text { Partnership of } \\
\text { bidder companies }\end{array}$ \\
\hline 5 & $\begin{array}{l}\text { The good ability } \\
\text { of investments } \\
\text { to finance the } \\
\text { project }\end{array}$ & 57.6 & 3 & $\begin{array}{l}\text { Sharing, } \\
\text { Enrichment }\end{array}$ & $\begin{array}{l}\text { Inviting powerful investors and proposing } \\
\text { attractive and profitable schemes }\end{array}$ & $\begin{array}{l}\text { Preliminarily } \\
1 / 10 \text { time of } \\
\text { the project }\end{array}$ & $8^{\text {th }}$ Anbohsazan \\
\hline 10 & $\begin{array}{l}\text { Partnership with } \\
\text { the region of the } \\
\text { scheme } \\
\text { landlords in the } \\
\text { profit of the } \\
\text { project }\end{array}$ & 37.8 & 4 & $\begin{array}{l}\text { Sharing, } \\
\text { Exploit }\end{array}$ & $\begin{array}{l}\text { Encouraging landlords to sell their properties } \\
\text { and sharing the scheme profit with them }\end{array}$ & $\begin{array}{l}\text { First half time } \\
\text { of the project }\end{array}$ & $\begin{array}{l}\text { Municipality of } \\
\text { Mashhad, } 8^{\text {th }} \\
\text { Anbohsazan }\end{array}$ \\
\hline 21 & $\begin{array}{l}\text { On credit } \\
\text { purchasing }\end{array}$ & 38.5 & 5 & Exploit & $\begin{array}{l}\text { Contracting with supplying networks and } \\
\text { factories and requesting them for whole sale } \\
\text { or on credit }\end{array}$ & $\begin{array}{l}\text { All the time } \\
\text { of the project }\end{array}$ & $\begin{array}{l}8^{\text {th }} \text { Anbohsazan, } \\
\text { Partnership of } \\
\text { bidder companies }\end{array}$ \\
\hline 22 & $\begin{array}{l}\text { Time sharing } \\
\text { selling }\end{array}$ & 38.5 & 6 & $\begin{array}{l}\text { Sharing, } \\
\text { Enrichment }\end{array}$ & $\begin{array}{l}\text { Advertising for the sale of residential units } \\
\text { as time sharing regarding the position of } \\
\text { them which are near the Holly Shrine }\end{array}$ & $\begin{array}{l}\text { Second half } \\
\text { time of the } \\
\text { project }\end{array}$ & $\begin{array}{l}\text { Municipality of } \\
\text { Mashhad, } 8^{\text {th }} \\
\text { Anbohsazan }\end{array}$ \\
\hline 2 & $\begin{array}{l}\text { Banks services } \\
\text { in slum areas }\end{array}$ & 35.2 & 7 & Exploit & $\begin{array}{l}\text { On time request for bank's low interest loans } \\
\text { for slum areas }\end{array}$ & $\begin{array}{l}\text { All the time } \\
\text { of the project }\end{array}$ & $8^{\text {th }}$ Anbohsazan \\
\hline 15 & $\begin{array}{l}\text { Increase in } \\
\text { properties worth }\end{array}$ & 32.256 & 8 & Exploit & $\begin{array}{l}\text { Increase in advertisement on investment } \\
\text { regarding the economical justifications of the } \\
\text { scheme }\end{array}$ & $\begin{array}{l}\text { Second half } \\
\text { time of the } \\
\text { project }\end{array}$ & $\begin{array}{l}\text { Municipality of } \\
\text { Mashhad, } 8^{\text {th }} \\
\text { Anbohsazan }\end{array}$ \\
\hline 18 & $\begin{array}{l}\text { Decrease in man } \\
\text { power services } \\
\text { due to recession }\end{array}$ & 30 & 9 & Exploit & $\begin{array}{l}\text { Providing a competitive conditions for } \\
\text { bidders to lessen the proposed prices of } \\
\text { material }\end{array}$ & $\begin{array}{l}\text { All the time } \\
\text { of the project }\end{array}$ & $\begin{array}{l}8^{\text {th }} \text { Anbohsazan, } \\
\text { Partnership of } \\
\text { bidder companies }\end{array}$ \\
\hline 19 & $\begin{array}{l}\text { Decrease in } \\
\text { construction } \\
\text { materials prices } \\
\text { due to the } \\
\text { recession }\end{array}$ & 30 & 10 & Exploit & $\begin{array}{l}\text { Providing a competitive conditions for } \\
\text { bidders to lessen the proposed prices of } \\
\text { construction services }\end{array}$ & $\begin{array}{l}\text { All the time } \\
\text { of the project }\end{array}$ & $\begin{array}{l}8^{\text {th }} \text { Anbohsazan, } \\
\text { Partnership of } \\
\text { bidder companies }\end{array}$ \\
\hline
\end{tabular}

As we see from the table, having an increase budget would be the best positive risk, which could benefit the outcome of the project. When there is an increase interest in investing in project, we must take advantage of such incidents and carefully allocate the budget to projects' activities. The other positive risk is to expedite the process of construction using mass production techniques, which reduce many setup costs. There are other positive risk factors such as having good partners and the ability to buy on credit. It is obvious that good partners could contribute the whole project, significantly.

\section{Acknowledgment}

The authors would like to thank the anonymous referees for their constructive comments on earlier version of this paper.

\section{Conclusions}

Regarding the construction needs and the necessity of development of urban infrastructures and specially the urban revitalization, the importance of attention to proper approaches for financing such projects is an inevitable fact. The financing procedures are designed regarding the condition of each 
project and so that there is not a unique prescription for all the projects. In attention to the investment approaches decreases the safety of achieving the desirable results and leads to mal management. Such failures may threat investor's financial resources and could lead to losses. Based on the research performed on the definition and evaluation risks of Saheb Alzaman Boulevard renewal project, it was understood that the delay in required land release, delay in scheme units sale, decrease in public attraction of invest, delay or disability to pre-selling the commercial units and decrease in purchase attraction and weakness in providing financial needs by the investors are the most significant threats.

In addition, increase in execution budget of the scheme, decrease in construction time, mass construction and application of novel technologies in construction and finally ability providing proper cash flow by the investors and financial providers are the main opportunities. Besides, the analysis reveals that the public private partnership in financing urban renewal project can increase the chance of hunting opportunities and avoid the threats. The main concern, which should be highly considered is that the majority of the scheme profits are originated from the commercial units sales. The most significant threat emerges while the buyers lose their enthusiasm to purchase the commercial unites due to the recessions or over supply of such units in the region. It seems authorities of urban renewal projects should devise approaches to preserve their desirable profits by lessening the construction costs and also the government as the main sponsor of such projects should eliminate any permit fees issued by municipalities or other relelevant governmental organizations. Undoubtedly, without governmental supports and financial exemptions we could not observe any considerable acceleration in introduction and implementation of urban revitalization projects.

\section{References}

Adiar A.S., Berry J.N., Mc Greal, W.S., Deddis, W.G., \& Hirst S.M. (1999). Evaluation of investor behavior in urban regeneration. Urban Studies, 36(2), 2031-2045.

Adair, A., Hutchison, N., Burgess, J., Roulac, S. (2005a). The appraisal of urban regeneration land: A contemporary perspective allowing for uncertainty. Journal of Property Investment \& Finance, 23(3), 213-233.

Adair, A., Berry, J., McGreal, S., Poon, J., Hutchison, N., Watkins, C., \& Gibb, K. (2005b). Investment performance within urban regeneration locations. Journal of Property Investment \& Finance, 23(1), 7-21.

Callender, M., \& Key, T. (1996). The total value of commercial property in the UK. paper presented at the Royal Institution of Chartered Surveyors Cutting Edge Conference, University of the West of England, Bristol.

Colin, S. (1998). In the twilight zone: A survey of PPPs in Sweden. Public productivity and management review, 21, 272-283.

Guy, S., Henneberry, J., \& Rowley, S. (2002). Development cultures and urban regeneration. Urban Studies, 39(7), 1181-1196.

Jenkinson, J. (2003). Private finance. Oxford Review of Economic Policy, 19(2), 323-334.

McGreal, W.S., Adair, A.S., Berry, J.N., Deddis, W.G., \& Hirst, S. (2000). Accessing private sector finance in urban regeneration: investor and non-investor perspectives. Journal of Property Research, 17(2), 109-31.

Rondinelli, D.A. (1990). Housing the urban poor in developing countries: The magnitude of housing deficiencies and the failure of conventional strategies are world-wide problems. American Journal of Economics and Sociology, 49(2), 153-166.

Yescombe, E.R. (2007). Public - private partnership: principles of policy and finance. Elsevier. 